\title{
Brome mosaic virus capsid protein regulates accumulation of viral replication proteins by binding to the replicase assembly RNA element
}

\author{
GUANGHUI YI, ${ }^{1,3}$ ESTER LETTENEY, ${ }^{2}$ CHUL-HYUN KIM, ${ }^{2}$ and C. CHENG KAO ${ }^{1,3}$ \\ ${ }^{1}$ Department of Biochemistry and Biophysics, Texas A\&M University, College Station, Texas 77843, USA \\ ${ }^{2}$ Department of Chemistry and Biochemistry, California State University, East Bay, Hayward, California 94542, USA
}

\begin{abstract}
Viruses provide valuable insights into the regulation of molecular processes. Brome mosaic virus (BMV) is one of the simplest entities with four viral proteins and three genomic RNAs. Here we report that the BMV capsid protein (CP), which functions in RNA encapsidation and virus trafficking, also represses viral RNA replication in a concentration-dependent manner by inhibiting the accumulation of the RNA replication proteins. Expression of the replication protein $2 \mathrm{a}$ in trans can partially rescue BMV RNA accumulation. A mutation in the CP can decrease the repression of translation. Translation repression by the $C P$ requires a hairpin RNA motif named the $B$ Box that contains seven loop nucleotides (nt) within the $5^{\prime}$ untranslated regions (UTR) of BMV RNA1 and RNA2. Purified CP can bind directly to the B Box RNA with a $K_{d}$ of $450 \mathrm{nM}$. The secondary structure of the B Box RNA was determined to contain a highly flexible 7-nt loop using NMR spectroscopy, native gel analysis, and thermal denaturation studies. The B Box is also recognized by the BMV 1a protein to assemble the BMV replicase, suggesting that the BMV CP can act to regulate several viral infection processes.
\end{abstract}

Keywords: positive-strand RNA virus; brome mosaic virus; capsid protein; RNA replication; RNA binding; translational inhibition; B Box; RNA structure; NMR

\section{INTRODUCTION}

RNA viruses serve as simple model systems for studies of protein-RNA interactions. They have already taught us much about translation, RNA-dependent RNA synthesis, and RNA encapsidation. They are also excellent systems to study the mechanisms that regulate the timing of molecular processes as well as the innate host defense systems (Voinnet 2005; Miller and White 2006; Takeuchi and Akira 2007).

For positive-strand RNA viruses, the genomic RNA must serve as template for translation, replication, and encapsidation (Buck 1996). Upon entry into the host cell, the virion disassembles and the viral RNA serves as a template for both translation and minus-strand RNA synthesis. Since translation and minus-strand RNA synthesis initiate from

\footnotetext{
${ }^{3}$ Present address: Department of Biology, Indiana University, Bloomington, IN 47405, USA.

Reprint requests to: C. Cheng Kao, Department of Biology, Indiana University, Bloomington IN 47405, USA; e-mail: ckao@indiana.edu; fax: (812) 856-5710.

Article published online ahead of print. Article and publication date are at http://www.rnajournal.org/cgi/doi/10.1261/rna.1375509.
}

different termini of the same RNA, the timing of the two processes must be carefully regulated. After progeny RNA is produced, another timing switch is needed to transition from translation and replication to RNA encapsidation and virion assembly.

Brome mosaic virus (BMV), a member of the alphaviruslike superfamily of RNA viruses, is a segmented positivestrand RNA virus. The BMV genome consists of three capped, messenger-sense genomic RNAs that share a common tRNA-like structure within the $3^{\prime}$ untranslated region (UTR). Genomic RNA1 and RNA2 encode nonstructural proteins $1 \mathrm{a}$ and 2a, respectively, which direct RNA replication (Noueiry and Ahlquist 2003). The 1a protein is a multifunctional protein, with an $\mathrm{N}$-terminal half that has $\mathrm{m}^{7} \mathrm{G}$ methyltransferase activity and a C-terminal half that contains helicase motifs (Ahola and Ahlquist 1999; Kong et al. 1999; Wang et al. 2005). 1a is a key factor for replicase assembly, recruiting the RNA-dependent RNA polymerase (RdRp) and viral RNAs to reconfigure the cellular membranes to form a mini-organelle called a spherule, inside of which RNA replication takes place (Schwartz et al. 2002, 2004). RNA2 encodes the BMV RdRp 
named 2a. Genomic RNA3 is a bicistronic RNA that encodes for the movement protein (MP) responsible for cell-to-cell spread and also for the capsid protein (CP). The MP is translated from the RNA3, and the CP is translated from a subgenomic RNA4 that is made using minus-strand RNA3 as the template (Miller et al. 1985).

The CPs of positive-strand RNA viruses are multifunctional proteins involved in many aspects of viral infection cycles and virus-host interactions. They are also of interest for use in vaccine production and for nanotechnology applications (Callaway et al. 2001; Dragnea et al. 2003; Rao 2006). The capsids from hepatitis $C$ virus and the Rubella virus can affect translation as well as RNA replication (Shimoike et al. 1999; Ilkow et al. 2008; Wolf et al. 2008). Bacteriophage MS2 capsid can bind to the viral RNA motif and then shut down replicase protein expression (Witherell et al. 1991). Neeleman et al. (2001) reported that the coat protein of Alfalfa mosaic virus (AMV), a member of the genus Alfamovirus in the Bromoviridae family, could bind to the $3^{\prime}$ end of viral RNA and enhance subgenomic RNA4 translation. The AMV CP could also regulate RNA synthesis by binding to the 3 ' ends of alfamovirus and ilarvirus RNAs to activate genome replication (Bol 2005; Guogas et al. 2005).

We determined that the BMV CP could bind to the promoter element in the 3' UTR that directs minus-strand RNA synthesis (Zhu et al. 2007). We seek to further dissect the cis- and trans-acting requirements of the $\mathrm{CP}$ in BMV RNA replication in planta. Overexpression of BMV CP was found to down-regulate translation from BMV RNA1 and RNA2, which, in turn, repressed RNA replication. Inhibition of translation is mediated through CP binding of a hairpin RNA with a 7-nucleotide (nt) loop in the 5' UTR of RNA1 and RNA2, called the B Box, which is recognized by the 1a protein for the assembly of the replicase factory.

\section{RESULTS}

\section{The BMV capsid protein can repress viral RNA replication}

The Agrobacterium expression system can be used to manipulate the expression level per cell by simply varying the concentration of the inocula (Gelvin 2003). We used this property to examine the function of the BMV CP on BMV RNA replication in Nicotiana benthamiana. The CP was transiently expressed by an Agrobacterium strain (A-pCP) harboring a T-DNA plasmid (pCP) that lacks BMV 5' and $3^{\prime}$ UTRs and hence is not subject to normal $\mathrm{BMV}$-associated regulations. Schematics of the expression constructs used in this study are shown in Figure 1A. Total RNA was isolated at $48 \mathrm{~h}$ post-inoculation (hpi), from $N$. benthamiana plants coinfiltrated with constant amounts of Agrobacterium cultures expressing the three BMV genomic RNAs and increasing concentrations of A-pCP. The viral
RNAs were detected by Northern blot assays using strandspecific probes. At the lowest concentration of A-pCP tested, a reproducible increase of both minus- and plusstrand RNA accumulation was observed in five independent experiments; while at higher concentrations of the CP, RNA accumulation was repressed in a concentrationdependent manner (Fig. 1B). A-pCP introduced at an $\mathrm{OD}_{595}$ of 1.0 resulted in decreases of minus- and plusstrand RNA to $\sim 20 \%$ or less compared to the vectorinoculated control (Fig. 1B).

The BMV CP is normally expressed from RNA4. To determine whether the effects observed required the presence of RNA4, we inoculated N. benthamiana plants with Agrobacterium cultures expressing only BMV RNA1, RNA2, and A-pCP. BMV RNA1 and RNA2 could replicate in the absence of BMV RNA3, although RNA3 could increase the accumulation of the BMV RNAs in plants (Janda and Ahlquist 1993; Gopinath et al. 2005). Consistent with the results with all three BMV genomic RNAs, the presence of A-pCP increased BMV RNA1 and RNA2 accumulation when lower culture concentrations of A-pCP were used, while accumulation was markedly inhibited at higher concentrations. These results show that the CP expressed from A-pCP is sufficient for the regulatory activities we observed.

Finally, we determined whether the concentration of infiltrated inocula correlated with CP expression. The lysates used in Figure 1C were subjected to a Western blot probed with anti-CP antibody, and a correlation between A-pCP and CP expression was observed (Fig. 1D). This result confirms that the expression level of the BMV CP can have multiple effects on BMV RNA accumulation.

\section{Analysis of the effects of the $C P$}

Overexpression of the CP could affect RNA stability, the translatability of the RNAs, RNA replication, or some combination of these. To better separate these possibilities, we first examined whether the CP will exert an effect on BMV RNA3 accumulation. BMV RNA3 can replicate and direct subgenomic RNA4 production in the presence of $1 \mathrm{a}$ and 2 a replication proteins produced in trans (French and Ahlquist 1987; Janda and Ahlquist 1993; Gopinath et al. 2005). A mixture of Agrobacterium strains expressing pla and $\mathrm{p} 2 \mathrm{a}$ that lacked BMV UTRs, BMV RNA3, and an 1.0 $\mathrm{OD}_{595}$ of A-pCP were infiltrated into $N$. benthamiana. RNA3 and RNA4 were found to accumulate at $75 \%$ of the mock-treated control (Fig. 2A), in contrast to the more pronounced inhibition seen in plants where all three BMV RNAs were expressed (Fig. 1B). We conclude that the CP can differentially affect the accumulation of the three BMV genomic RNAs through a mechanism that does not directly involve RNA3 accumulation. We note that RNA1 and RNA2 could titrate CP molecules from RNA3. Therefore, any inhibitory effects on RNA3 should be more pronounced in the absence of other BMV RNAs. 
A

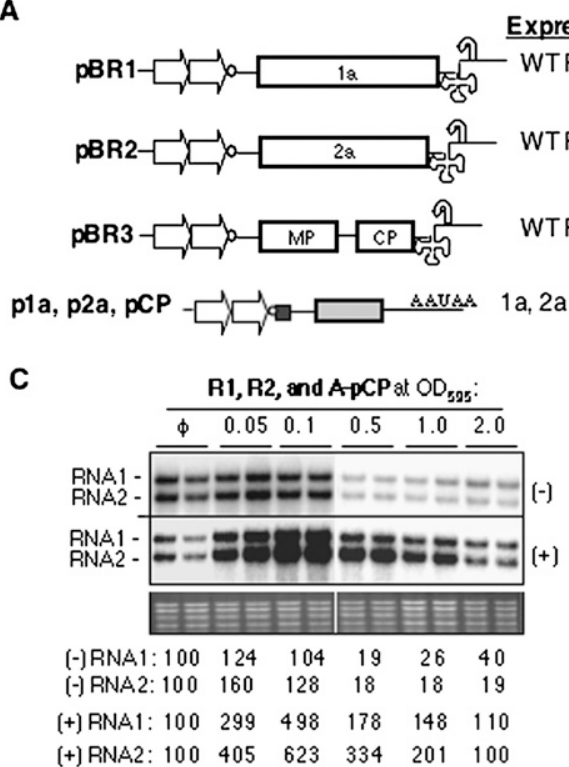

B

$\begin{array}{lllllll}\mathrm{A}-p \mathrm{pP}\left(O D_{g q s}\right): 0 & 0.03 & 0.1 & 0.2 & 0.5 & 1.0 & 2.0\end{array}$

$(-)$

R2 -

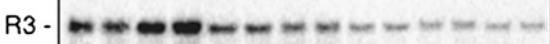

$+)$

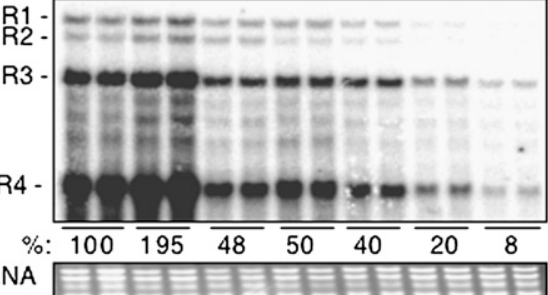

D

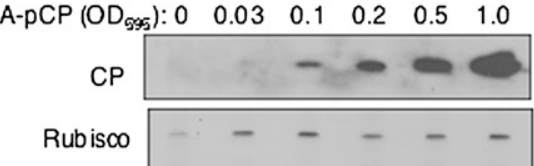

FIGURE 1. The BMV capsid protein (CP) can regulate BMV RNA accumulation. (A) Schematic of the constructs used in this study. The relevant portions of the T-DNA plasmids are shown with the names to the left. The two arrows represent the tandem CaMV $35 \mathrm{~S}$ promoters used to drive transcription. The named of protein $(s)$ encoded by the RNAs are shown inside rectangles. The 3' UTR is represented by a cloverleaf. The curved arrow represents a cis-acting ribozyme that will generate the bona fide $3^{\prime}$ terminus of the BMV RNAs. The cDNAs used for transient expression of BMV proteins 1a, 2a, and CP contain a translational enhancer in the $5^{\prime}$ UTR upstream from the protein-coding sequence (small black square) and a polyA processing signal (AAUAA) $3^{\prime}$ of the protein-coding sequence. (B) Effects of transient BMV CP expression on BMV RNA accumulation. Leaves of N. benthamiana plants were infiltrated with a mixture of Agrobacterium cultures expressing BMV CP with a mixture of cultures that expressed three genomic RNAs (at $\mathrm{OD}_{595}$ of 0.1 ). Total RNA was isolated at $48 \mathrm{hpi}$, and minus- and plus-strand viral RNAs were detected by Northern blot using strand specific probes as described by Gopinath et al. (2005). The agarose gel image of ethidium bromide-stained cellular RNA (cRNA) served as an RNA loading control. Quantification of the minus- and plus-strand RNAs shown as percentages of the wild-type RNAs in $B .(C)$ Effects of the CP on BMV RNA1 and RNA2 replication. $N$. benthamiana leaves were infiltrated with Agrobacterium cultures expression BMV RNA1 and RNA2 (at an $\mathrm{OD}_{595}$ of 0.1). Total RNAs were isolated and analyzed as described in $B$. (D) Western blot of CP expression level in $N$. benthamiana plants infiltrated with different concentrations of Agrobacterium expressing BMV CP. The primary antibody was a rabbit polyclonal antibody purchased from the ATCC. A Coomassie blue-stained small subunit of Rubisco was used as a protein loading control.

To address whether CP expression could affect RNA1 and/or RNA2 stability, we used semi-quantitative RT-PCR. Agrobacterium expressing either BMV RNA1 or RNA2 was coinoculated with several concentrations of A-pCP. Total RNA was isolated at $24 \mathrm{hpi}$ and treated with RNase-free DNase I. Equal amounts of total RNA were used for RT and then amplified by PCR with BMV-specific primers and primers for the $18 \mathrm{~S}$ rRNA as a control. In addition, the RNA isolated from the sample with $\mathrm{pBR} 1$ or $\mathrm{pBR} 2$ and a 1.0 $\mathrm{OD}_{595}$ of A-pCP was used directly in PCR reactions without undergoing reverse transcription, as a control for contaminating DNAs (Fig. 2B, lane C). The absence of a band in these reactions shows that the signals are generated from RNAs. Importantly, no inhibitory effect was observed for the accumulation of either RNA1 or RNA2 (Fig. 2B), suggesting that the CP's inhibitory effects on BMV RNA accumulation were not primarily through an effect on the stability of RNA1 or RNA2. Additional real-time RT-PCR results showing that the $\mathrm{CP}$ did not affect BMV RNA1 and RNA2 accumulation are presented as Supplemental Figure 1.

The results thus far suggest that the CP may affect BMV RNA accumulation through products made from RNA1 and/or RNA2. If the CP inhibited the accumulation of the replication proteins such as $2 \mathrm{a}$, the presence of 2 a protein in trans should overcome the inhibitory effects of the CP. A-pCP at an $\mathrm{OD}_{595}$ of 1.0 was coinfiltrated with increasing concentrations of Agrobacterium expressing 2a (A-2a) along with constant amounts of the cells expressing the three BMV RNAs. The presence of A-2a rescued the accumulation of RNA1, RNA3, and subgenomic RNA4 in a concentrationdependent manner (Fig. 3). RNA2 was notably absent in this experiment, likely due to the A-2a mRNA causing silencing of RNA2, as has been observed previously (Iyer and Hall 2000; Yi et al. 2007). These results are consistent with a model wherein the CP regulates BMV RNA replication through controlling the level of BMV RNA replication protein(s).

\section{$C P$ repressed reporter construct expression}

Next, we use RNA reporter constructs to dissect the inhibitory effects of the CP. The BMV protein-coding sequences in RNA1 and RNA2 were replaced by GFP in constructs named 1GFP1 and 2GFP2 (Fig. 4A) while in 
A

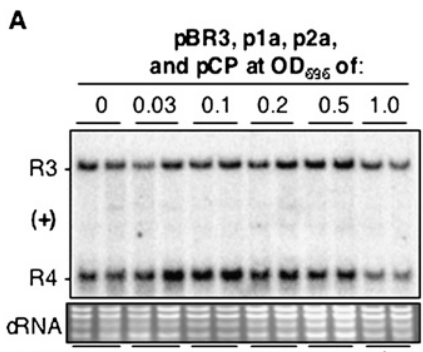

$\mathrm{R} 3 \%: \overline{\overline{100}} \overline{85} \overline{97} \overline{99} \overline{120} \overline{75}$

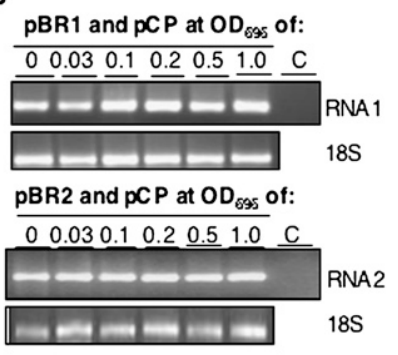

FIGURE 2. Effects of expression of BMV capsid protein on RNA1 or RNA2 stability. (A) The CP has only a moderate inhibitory effect on BMV RNA3 and RNA4 production. Agrobacterium expressing the replication proteins $1 \mathrm{a}$ and $2 \mathrm{a}$ were coinfiltrated into $\mathrm{N}$. benthamiana along with culture expressing BMV RNA3. The RNAs were extracted 48 hpi and detected by Northern blots probed to detect the BMV 3' UTR. The relative amounts of the RNA in this experiment were quantified by Phosphorimage analysis. The results are reproducible in two independent replicates. (B) RT-PCR to detect the level of transcribed RNA from the T-DNA vector in N. benthamiana in the presence of CP expression. Agrobacterium expressing RNA1 or RNA2 was coinfiltrated with different concentrations of culture expressing BMV CP. Total RNA was isolated 24 hpi and treated with RNase-free DNase I. After phenol/chloroform purification and precipitation, equal amounts of RNA were subjected to RT-PCR with appropriate primer sets. $18 \mathrm{~S}$ ribosomal RNA was amplified from the same samples as a loading control. In the reaction marked "C," the sample infiltrated with $1.0 \mathrm{OD}_{595}$ was not subjected to reverse transcription before amplification by PCR. The absence of product in this lane demonstrates that the samples were not contaminated with DNA.

RNA3, the MP, intercistronic region, and the CP coding sequences were all replaced by the GFP cDNA to result in construct 3GFP3. In the absence of CP expression, all three reporters expressed GFP, as determined by microscopic examination (Fig. 4B, left panel). In the presence of $\mathrm{CP}$, GFP expressing from 1GFP1 and 2GFP2 was significantly inhibited, while there was only a mild effect on GFP production from $3 \mathrm{GFP} 3$ (Fig. 4B, right panel). To better quantify GFP levels, we performed Western blot analysis of leaf discs pooled from separately infiltrated areas of each plant. Consistent with the results from microscopic examination, GFP accumulations from 1GFP1 and 2GFP2 were inhibited by CP expression (Fig. 4C). RT-PCR of the same samples showed that the levels of the GFP mRNAs were not affected by the presence of CP (Fig. 4C, bottom panel). In six independent experiments, we observed some variation in GFP expression from the 1GFP1 reporter (three experiments with obvious inhibition, three with only mild or no obvious inhibition of GFP levels). However, expression from 2GFP2 was severely repressed in all six experiments. Therefore, 2GFP2 was used for additional analyses below.

\section{A substitution in the $\mathrm{CP}$ prevented translation repression}

To demonstrate further that the overexpressed CP is responsible for the inhibition of protein accumulation, we

analyzed the effects of four single amino acid alanine substitutions in the CP. Three of the substitutions were in the globular domain of the CP (R103A, S129A D139A), and one was in the $\mathrm{N}$-terminal tail that is rich in basic residues (K7A). All four mutants were expressed at levels comparable to that of wild-type (WT) CP (Fig. 5A; data not shown). Agrobacterium expressing each mutant CP was infiltrated into $N$. benthamiana at an $\mathrm{OD}_{595}$ of 1.0 along with 2GFP2. Two of the mutant CPs retained the inhibition of GFP production by 2GFP2. However, mutants K7A and D139A had reduced inhibitory effect on GFP levels, with D139A being the more affected of the two (Fig. 5B; data not shown). To extend this analysis, three concentrations of mutant D139A were compared with equal concentrations of the WT CP. While the WT CP reduced GFP levels from those of 2GFP2 when infiltrated at an $\mathrm{OD}_{595}$ of $0.8, \mathrm{D} 139 \mathrm{~A}$ did not show pronounced inhibitory effect until it was infiltrated at an $\mathrm{OD}_{595}$ of 1.5 (Fig. 5C). Calhoun and Rao (2008) showed that D139A is a mutation that prevents BMV virion formation, and hence, we did not pursue analysis of D139A further for this work. However, these results confirm that the BMV CP is responsible for the activities we have observed.

\section{Cis-acting element required for CP-mediated translation inhibition}

To determine whether the $5^{\prime}$ or the $3^{\prime}$ UTR of RNA2 was required for $\mathrm{CP}$ repression of protein production, chimeric RNAs with exchanges of UTRs between RNA3 and RNA2 were examined. The names of the chimeric RNAs denote the source of the $5^{\prime}$ and $3^{\prime}$ UTRs (e.g., 3GFP2 has the $5^{\prime}$ UTR of RNA3 and the $3^{\prime}$ UTR of RNA2). The expression from $3 \mathrm{GFP} 3$, which is less sensitive to CP inhibition, served

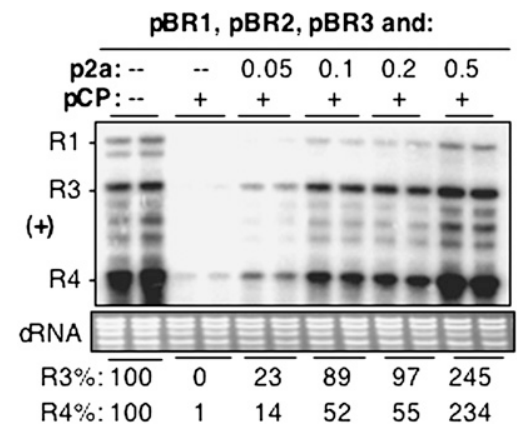

FIGURE 3. Coexpression of BMV 2a protein can rescue BMV RNA accumulation. Agrobacterium cultures expressing three genomic RNAs were either infiltrated into $N$. banthamiana plants along with a culture harboring pCP (at $\mathrm{OD}_{595}$ of 1.0) or infiltrated with culture expressing $\mathrm{pCP}$ along with increasing concentrations of a culture that can express the 2a protein. Viral RNAs were detected by Northern blot assay. The levels of RNA3 and RNA4 were quantified and shown below the cellular RNA (cRNA) loading control. Amounts of RNA3 and RNA4 were determined by Phosphorimage analysis and normalized to the sample lacking cultures expressing both pCP and p2a. 
A
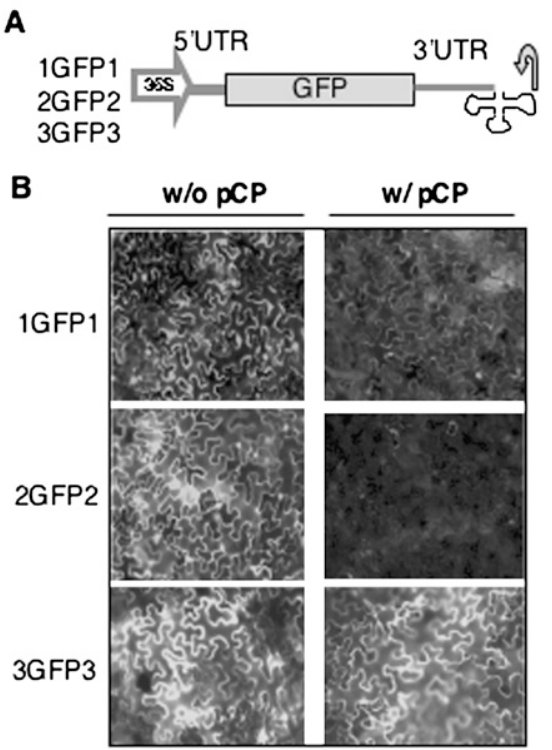

C

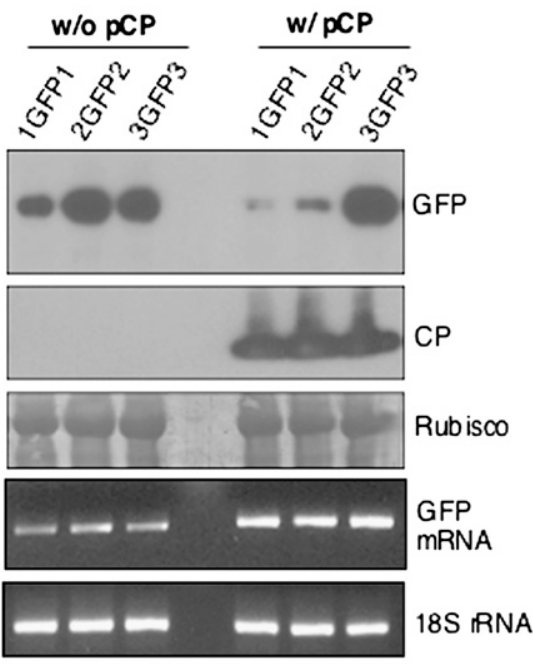

RNA motif is required for the inhibition of GFP production from the 5' UTR of RNA2.

\section{The BMV CP can bind the B Box RNA motif}

We hypothesize that the CP could bind directly to the B Box of RNA1 or RNA2 to mediate translation regulation. To determine the affinity of the $\mathrm{CP}$ for the B Box, WT B Box RNA motifs were chemically synthesized with a $5^{\prime}$ fluorosceine and used in fluorescent anisotropy experiments until saturation was reached. The binding isotherm was best fitted to the Hill equation to reveal that the $\mathrm{CP}$ binds to $\mathrm{B}$ Box RNA with an affinity of $\sim 450 \mathrm{nM}$ and a Hill constant of 2.0 (Fig. 7B), indicating cooperative $\mathrm{CP}$ binding to the $\mathrm{B}$ box RNA. The basis for the cooperative binding is presently unclear.

To compare the relative binding to the B Box and B Box mutants, we radiolabeled the WT B Box RNA and several RNAs with changes in the loop nucleotides as well as one with the $\mathrm{B}$ Box sequence from BMV RNA3. The RNA3 B box named R3Bb differs from the RNA2 B box by one loop nucleotide (Fig. 7A). Since the probes were labeled in separate reactions, the signal in the cross-linked band was normalized to the probe. The BMV CP preferentially

as the negative control. The expression of GFP was detected by microscopic examination and Western blot, and the results were consistent (Fig. 6A, top panels; data not shown). In the presence of $\mathrm{CP}$, replacement of the $5^{\prime}$ UTR of RNA2 in construct 3GFP2 caused a loss of CPmediated repression (Fig. 6A).

The 5' UTR of BMV RNA2 can be divided into three subdomains (Fig. 6B). To address which subdomain is required for $\mathrm{CP}$-dependent translation inhibition, each was individually deleted, resulting in constructs $\Delta \mathrm{A}, \Delta \mathrm{B}$, and $\Delta \mathrm{C}$. In the absence of the $\mathrm{CP}$, all the deletion mutants expressed detectable GFP when analyzed by Western blot (Fig. 6C, top panel). In the presence of CP, GFP accumulation was observed only with the $\Delta \mathrm{A}$ mutant that lacked subdomain A (Fig. 6C, bottom panel). The B Box motif lies at the apex of subdomain $\mathrm{A}$ and is important for replicase assembly (Chen et al. 2001; Schwartz et al. 2002, 2004). A construct named $\Delta \mathrm{Bbox}$, which deleted the $\mathrm{B}$ Box, was found to not be subject to CP-mediated inhibition (Fig. $6 \mathrm{D})$. These mapping studies demonstrate that the B Box cross-linked to the B Box of RNA2 by two- to fivefold when compared with other probes (Fig. 7C, top panel). An unrelated RNA-binding protein, Nsp15 (Bhardwaj et al. 2008), did not preferentially cross-link to the WT B Box. We note that the B Box of RNA2 is identical to that of RNA1 and that these results suggest that the loop nucleotides in the hairpin of the B Box motif contribute to $\mathrm{CP}$ binding. Finally, to confirm this preferential recognition of the B Box motif, we used a gel mobility shift assay. Again, the WT B Box was preferentially recognized when compared with the variants (Fig. 7D).

\section{Structural analysis of the B Box motif}

The BMV CP could preferentially recognize an RNA motif with a 3-nt loop that contains the core promoter for minus-strand RNA synthesis (Zhu et al. 2007). The triloop was shown by previous NMR spectroscopy to fold into a structure called a clamped adenine motif (CAM), where there are extensive base stacking and electrostatic interactions 
A
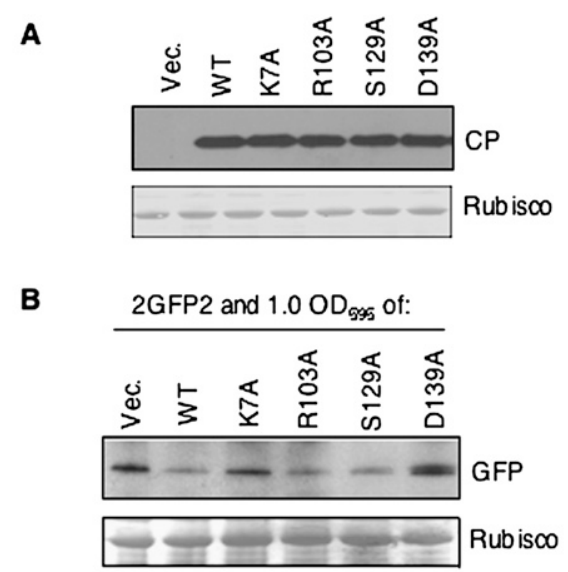

C

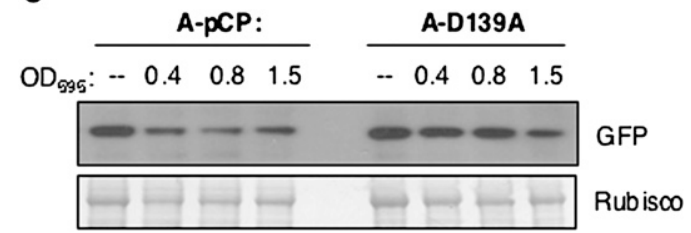

FIGURE 5. Mutations in the $\mathrm{CP}$ can affect the inhibition of reporter protein production. (A) Expression of the mutant BMV CPs in $N$. benthamiana. The mutant CPs were all constructed by site-directed mutagenesis and verified to have only the intended mutation. The amount of CP produced in $N$. benthamiana was examined by a Western blot probed with antiserum to the BMV CP. The small subunit of the Rubisco protein was used as a loading control. (B) A survey of the effects of the mutant CPs on the inhibition of GFP production from the 2GFP2 reporter. $N$. benthamiana plants were infiltrated to express $2 \mathrm{GFP} 2\left(\mathrm{OD}_{595}\right.$ of 0.2$)$ and either a culture containing the empty vector, the wild-type $\mathrm{CP}$, or a select mutant $\mathrm{CP}$. The leaves were macerated at $48 \mathrm{hpi}$ and subjected to Western blot analysis detecting GFP. (C) Further examination of the effects of D139A on GFP accumulation from construct 2GFP2. The densities of the cultures expressing the WT CP or the D139A mutant are shown above the Western blot image.

between the loop nucleotides and the two closing base pairs (Kim et al. 2000). This set of observations led us to ask whether the B Box motif structurally resembles the CAM.

Preliminary analysis using Mfold confirmed that the B Box motif is likely to form a hairpin structure with a 7-nt loop. However, to examine this experimentally, 19-nt RNAs containing a WT or a mutant B Box (mB Box) (Fig. 8A) were prepared by in vitro transcription, purified from preparative denaturing gels, and used for further characterizations.

Nondenaturing gel electrophoresis could be used to investigate overall conformational differences in small RNA motifs (Kim and Kao 2001; Zhang et al. 2003). The WT B Box RNA reproducibly showed a slower mobility in comparison to the $\mathrm{mB}$ Box RNA in a native gel, suggesting that it exists in a more loose conformation than the $\mathrm{mB}$ Box. Consistent with a more dynamic loop structure, the WT B Box RNA migrated slower than an 18-nt RNA named $-9 /-22$ that contains hairpin with a 6-nt loop.
Inclusion of $\mathrm{Mg}^{2+}$ in the native gel analysis did not affect the relative mobility of the WT and $\mathrm{mB}$ Box RNA (C.H. Kim, unpubl.). Notably, both the WT and $\mathrm{mB}$ Box RNAs exist primarily as monomers, as evidenced by the presence of a single band (Fig. 8B), indicating the formation of an intramolecular hairpin. The fact that the RNAs exist as monomers allows us to analyze the intramolecular interactions in these RNAs.

The thermodynamic properties of the WT B Box RNA were examined further. The WT B Box RNA shows a slightly lower melting temperature $\left(\mathrm{T}_{\mathrm{m}}\right)$ than the $\mathrm{mB}$ Box RNA (Fig. $8 \mathrm{C}$ ), consistent with the results from the nondenaturing gel that the WT B Box forms a more open conformation compared with the $\mathrm{mB}$ Box. No significant differences in the denaturation profiles of the two RNAs were observed in the UV melt studies despite the two RNAs having differing loop nucleotides. The addition of $1 \mathrm{mM} \mathrm{MgCl}_{2}$ to the reaction increased the $T_{m}$ by several degrees but did not alter

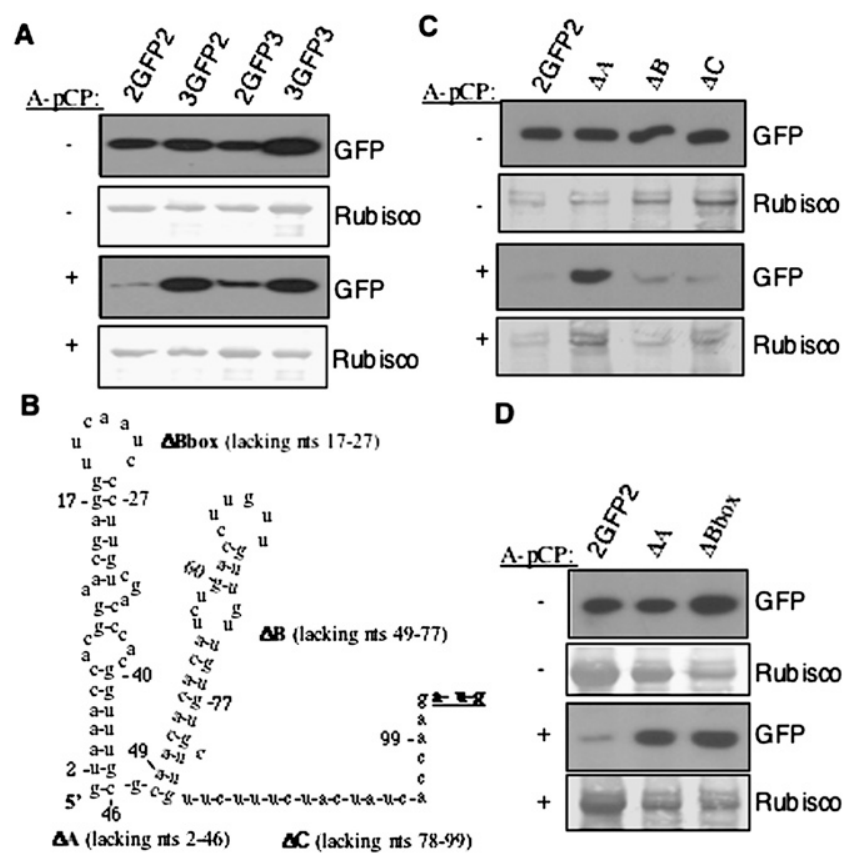

FIGURE 6. Mapping the cis-acting element(s) in the UTR of BMV RNA2 required for CP-mediated translation inhibition. (A) The 5' UTR of RNA2, but not RNA3, contains the cis-element required for translation regulation. Agrobacterium cultures expressing reporter RNAs containing combinations of the $5^{\prime}$ and $3^{\prime}$ UTRs of RNA2 and RNA3 were infiltrated into $N$. benthamiana leaves along with cultures expressing either the empty vector or the BMV CP. GFP was detected by anti-GFP antibody. The slice labeled "Rubisco" is from an SDSPAGE gel stained with Coomassie blue, which served as a loading control for the Western blotting. (B) Secondary structure of the $5^{\prime}$ UTR of BMV RNA2 from nucleotide 1 to the translation initiation codon. The structure was modeled with the Mfold program (Zuker, 2003). The names of the constructs with deletions within the $5^{\prime}$ UTR of 2GFP2 are shown in bold. (C) Effects of deletions in the RNA2 5' UTR on GFP accumulation in the absence or presence of exogenously provided CP. (D) Further examination of the effect of B Box deletion on GFP accumulation from $2 \mathrm{GFP} 2$. 
A

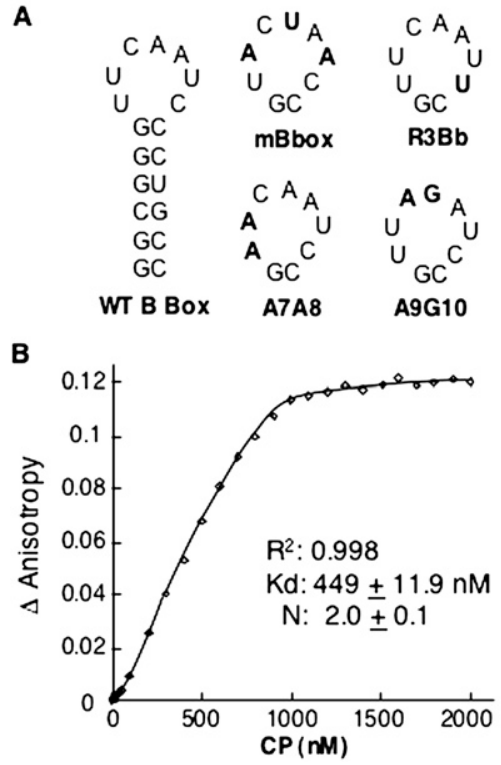

C
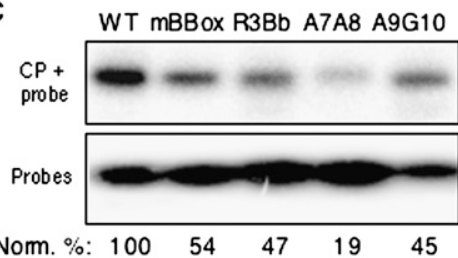

Norm. \%: $100 \quad 54 \quad 47 \quad 19 \quad 45$

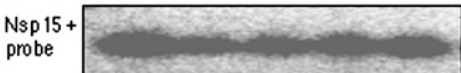

Probes

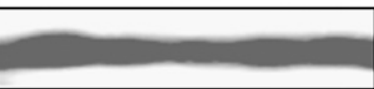

D

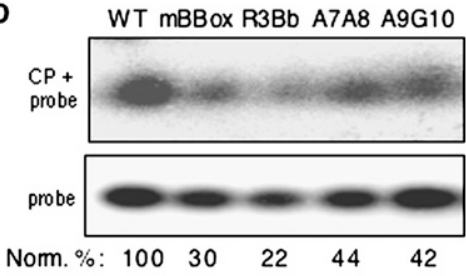

FIGURE 7. Protein-RNA binding assay in vitro. (A) Structure and sequence of WT B box and the mutants. The RNA structure was modeled with the Mfold program (Zuker 2003). Substitutions in the loop sequence are shown in bold, and the names are shown below the RNA structure. (B) Determination of the CP-RNA binding affinity by anisotropy experiment with fluorescence-labeled WT B box RNA. The fluorescein-labeled RNA was at $0.2 \mu \mathrm{M}$ in a buffer containing $50 \mathrm{mM}$ Tris $(\mathrm{pH} 7.5)$ and $50 \mathrm{mM} \mathrm{NaCl}$; BMV capsid protein was added to a final cumulative volume of less than $5 \%$ of the sample. All data were corrected for the background intensity of the buffer. Binding data were fitted into the Hill Equation using KaleidaGraph software (Synergy Software). (C) UV-cross-linking assay. About 100 ng of CP was UV crosslinked with radioactively labeled WT B Box or mutants as described in Material and Methods. "Probes" denotes the labeled RNAs used in the cross-linking assay. $(D)$ Electrophoretic mobility shift experiment of BMV CP and RNAs. The radioactively labeled RNAs were incubated with $500 \mathrm{ng}$ of purified CP at RT for $30 \mathrm{~min}$ and then subjected to electrophoresis in a native gradient gel of $3 \%-12 \%$ (Invitrogen) as described by the manufacturer. The quantification was normalized with the probes used in the experiment.

relative denaturation profiles of the two RNAs (Fig. 8C, inset). This data indicates that there are some transient interactions between loop nucleotides in the WT B Box, although these interactions are not affected by the three substitutions in the $\mathrm{mB}$ Box. The calculated enthalpy of melting $\Delta \mathrm{H}\left(\mathrm{T}_{\mathrm{m}}\right)$ for the WT B Box was $-62.7 \mathrm{kcal} / \mathrm{mol}\left(\mathrm{T}_{\mathrm{m}}=\right.$ $77.6^{\circ} \mathrm{C}$ ), assuming a two state helix-coil transition (Petersheim and Turner 1983), while the predicted $\Delta \mathrm{H}^{\circ}$ for the WT B Box RNA sequence in a solution with $1 \mathrm{M} \mathrm{NaCl}$ (Turner et al. 1988) is $-58.1 \mathrm{kcal} / \mathrm{mol}$ (using the nearest neighbor thermodynamic parameters) (Zuker et al. 1999), indicating that the 7-nt loop does contribute somewhat to the thermal stability of the hairpin conformation.

Finally, the overall conformational characteristics of the WT Box and the $\mathrm{mB}$ Box were investigated using NMR spectroscopy. When guanine and uracil form WatsonCrick base pairs in an RNA molecule, the exchange rates of their imino protons with water protons decreases, which produces sharp resonance peaks for the imino protons in NMR spectra and provides useful information about RNA secondary structure. Both the WT B Box and mB Box sequences show multiple sharp imino proton peaks that represent the formation of the base pairs in their stem region (Fig. 8D). The spectra of the $\mathrm{mB}$ Box has an additional peak associated with G6 (Fig. 8D) that is less relevant to the $\mathrm{B}$ Box function and is analyzed in Supplemental Figure 2. For the WT B Box, each imino proton peak has been assigned to its corresponding base using the pattern of the NOE cross peaks between neighboring imino protons in various Water NOESY experiments (see Materials and Methods; Supplemental Fig. 3). The expected ${ }_{4} \mathrm{GU}_{16}$ base pair is confirmed by the presence of unusually strong intra-base-pair NOE cross peaks between THE G4 and U16 imino protons as well as their unique up-field chemical shift values (Kim et al. 2000). While a small portion of the RNA may exist in a minor conformation (Fig. 8D, inset), the presence of the strong imino peaks from the ${ }_{4} \mathrm{GU}_{16}$ base pair clearly indicates that the seven nucleotide-long hairpin loop is the dominant conformation for the WT B Box RNA. No appreciable imino proton peak from any of three Us in the loop of the WT B Box were observed, indicating that these protons may well be exposed to the aqueous solution. Along with this observation, the absence of many H5H6 cross peaks of pyrimidine bases in DQF-COSY spectra (data not shown) suggests that the conformation of the WT B Box loop is quite flexible. Overall, these preliminary NMR results suggest that the conformation of the WT B Box loop is quite different from the compact structure of CAM observed in the tri-loop in the core promoter for minus-strand RNA synthesis.

\section{DISCUSSION}

In addition to encapsidation and trafficking from the initial site of infection, the viral $\mathrm{CP}$ is increasingly appreciated as an important regulator of viral gene expression, RNA replication, and in tempering host responses (Neeleman et al. 2001; Bendahmane et al. 2002; Qu et al. 2003; Guogas et al. 2005). We demonstrate that by perturbing the abundance of the BMV CP, an inhibitory effect on the translation from genomic RNA2, which encodes the 2a RdRp, was revealed. An unexpected result was that the inhibition was through the RNA motif that also regulates the formation of the BMV replicase (Schwartz et al. 2002, 2004). We have previously identified that the CP can recognize the promoter for BMV genomic minus-strand 
A

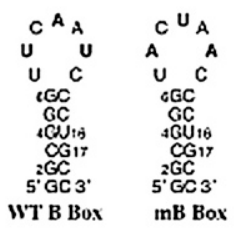

B

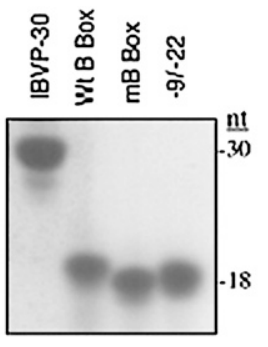

C

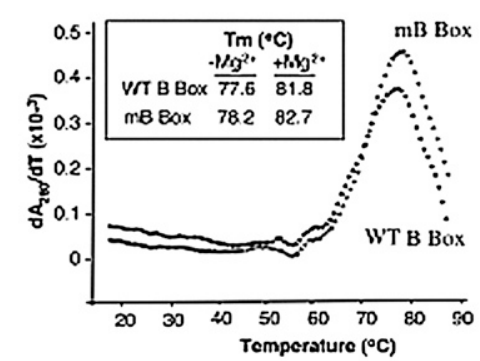

D

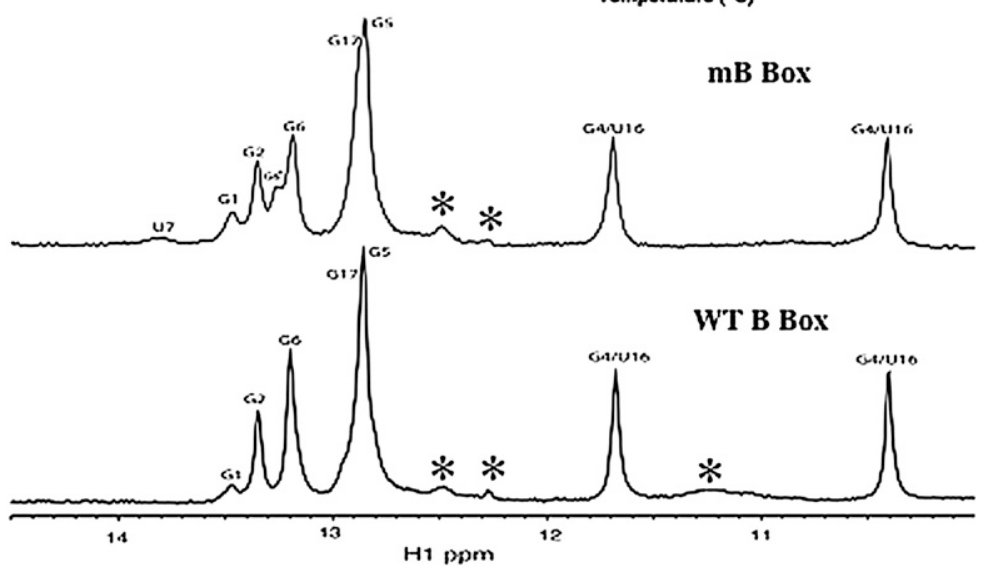

FIGURE 8. Analysis of the B Box RNA structure. $(A)$ Sequences of the B Box RNA motif and a mutant, mB Box, used in the analysis. (B) Mobilities of the WT and mutant B box RNAs in a 15\% native gel. Two RNAs served as markers for RNA conformations: IBVP-30mer (a 30-nt RNA with an 8-nt RNA loop and an 11 base-pair [bp] stem) and -9/-22 (an 18-nt RNA with a 6-nt loop with a 6-bp stem). (C) The UV denaturation profiles of the WT and mutant B Box RNA motifs. The first temperature derivatives of the absorbance at $260 \mathrm{~nm}\left(\mathrm{dA}_{260} / \mathrm{dT}\right) \mathrm{were}$ plotted against different temperatures. The maximum point of each plots represents the melting temperature $\left(\mathrm{T}_{\mathrm{m}}\right)$ of each RNA motif. All RNAs were in a phosphate buffer $\left(\mathrm{pH}\right.$ 6.5) containing $100 \mathrm{mM} \mathrm{NaCl}$. The inset summarizes the Tm of the WT and mutant B Box RNAs and also the $\mathrm{T}_{\mathrm{m}}$ in the same buffer amended with $1 \mathrm{mM} \mathrm{MgCl}_{2}$. (D) $1 \mathrm{D}$ NMR analysis of the WT and a mutant version of the B Box RNA. The imino proton spectra of WT B Box and mBBox at $10^{\circ} \mathrm{C}$ are shown. The spectra were taken at $\mathrm{pH} 5.7$ using a $500-\mathrm{MHz}$ Varian VNMRS spectrometer. The peaks identified as ${ }^{\star}$ represent the minor conformation. $6^{*}$ in the mBbox spectrum is suspected to be G6 in another conformation in which U7 also forms a UA base pair. The inset represents our interpretation of the major and minor conformations of the B Box RNA. While the predicted $\Delta \mathrm{G}$ values for the major and minor conformations are comparable, NMR analysis showed that the alternative conformation is extremely flexible, which may exist in a minor conformation. This might be due to the destabilizing presence of the internal $U$ bulge in the middle of the stem.

RNA synthesis (Zhu et al. 2007) through a 3-nt loop sequence that forms a CAM. An analysis of the secondary structure of an RNA containing the B Box motif competent for $\mathrm{CP}$ binding showed that the loops of the two RNAs do not possess a common structural element. Altogether, these results link the BMV $\mathrm{CP}$ to four processes critical to successful BMV infection: virion formation, translation, replicase formation, and minus-strand RNA synthesis. In addition, since the $\mathrm{CP}$ is translated from BMV subgenomic RNA4, this regulation could represent a feedback loop between transcription and the rest of the infection process. How the CP can recognize distinct RNA elements with specificity remains to be elucidated further.

To integrate the results of this work with information from other studies, we propose the schema shown in Figure 9. At the earliest stage of infection, the three genomic RNAs enter the cell's cytoplasm. Genomic RNA1 and RNA2 can serve as templates for the translation of the replication proteins 1a and 2a. 1a induces spherule formation at the ER membrane (Ahlquist 2006) and recruits RNA template as well as binds the 2a polymerase and/or host factor(s) (Kao and Ahlquist 1992; Chen and Ahlquist 2000; Chen et al. 2001). The progeny RNAs will serve as the template for the synthesis of additional BMV proteins, including the CP. At low concentrations of the $\mathrm{CP}$, it may primarily exist as monomers and/or dimers that might differentially bind to specific RNA motifs, such as the CAM for genomic RNA replication (to modulate replication) (Zhu et al. 2007) or the B Box (to shut down translation). At higher concentrations of the $\mathrm{CP}$, as would normally be the case later in the infection process, the BMV CP could bind to both the promoter for minus-strand RNA synthesis and the B Box to affect translation. The CP binding would also compete with the la protein for binding to the B Box motif (Yi and Kao 2008). At the present time, we have determined that the CP has a $K_{\mathrm{d}}$ of $\sim 700 \mathrm{nM}$ and $450 \mathrm{nM}$ for small RNAs containing the CAM and the B Box, respectively. Due to the 1a protein being tightly associated with the endoplasmic membranes (Chen and Ahlquist 2000; Schwartz et al. 2004), we cannot currently determine its affinity for the B Box. 


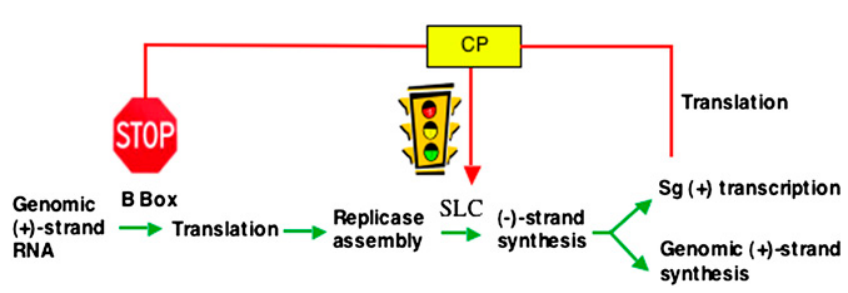

FIGURE 9. Model of the processes in BMV infection that are regulated by the BMV CP. The different steps in BMV infection are shown. The stop sign or the traffic light denote where the CP could exert an inhibitory effect, a variable effect, respectively.

We also expect that these affinities could vary with the oligomerization state of the $\mathrm{CP}$, the lengths of the RNAs, and/or possible association with other BMV proteins. The BMV CP has been demonstrated to copurify with active replicase complex (Bujarski et al. 1982), and there is precedent in AMV, where the $\mathrm{CP}$ interacts with the replication proteins (Reichert et al. 2007). We note that we have not examined the effects of the CP expressed from RNA4, but the $\mathrm{CP}$ expressed from A-pCP can be used in encapsidation reactions (data not shown), and we do not expect it to be structurally different than the CP expressed from RNA4.

We do not have evidence so far that the BMV CP has a regulatory effect on protein production from RNA3. RNA3 has a B Box in its intercistronic region, not in its 5' UTR. If the $\mathrm{CP}$ regulates protein production from RNA3 and/or RNA3a, a prematurely terminated version of RNA3 that encodes the MP (Wierzchoslawski et al. 2006), it will do so by a mechanism different than in RNA1 and RNA2.

There appears to be a concerted effort to keep the level of BMV RdRp low. Using the yeast as surrogate host, it has been demonstrated that the subdomain B of the 5' UTR of RNA2 can attenuate 2 a polymerase expression (Noueiry et al. 2000). Indeed, 2a could be expressed from a replication-defective RNA and provide sufficient $2 \mathrm{a}$ for the replication of all of the BMV RNAs (Iyer and Hall 2000; Gopinath et al. 2005). CP binding to the $\mathrm{B}$ box of RNA2 provides yet another mechanism to down-regulate 2 a polymerase translation. Careful control of 2a levels by multiple mechanisms may prevent the accumulation of viral RNA replication intermediates that could be detected by the host innate immunity responses or serve to initiate siRNA response.

\section{Final comments}

The effects of the CP on the accumulation of BMV RNA replication proteins should be considered as a part of the timing switches to synchronize the different steps required for successful BMV infection. Other steps include the mutual interference between BMV subgenomic RNA4 transcription and genomic RNA replication (Grdzelishvili et al. 2005) and the communication between the BMV replication proteins and the encapsidation of BMV RNAs (Annamalai and Rao 2005). Additional characterization of the interactions between viral molecules should be informative regarding other layers of regulation of viral processes that will find parallels in cellular processes. Finally, since the BMV CP can bind both the promoter for minusstrand RNA synthesis (Zhu et al. 2007) and the structurally distinct $\mathrm{B}$ Box motif, the $\mathrm{CP}$ could have the ability to recognize more than one RNA motif and exert regulatory effects. A prediction of this model is that mutations in the $\mathrm{CP}$ can differentially affect RNA replication and regulation of translation. Initial insight into this regulation has already been revealed by the CP mutation, D139A (Fig. 5).

\section{MATERIALS AND METHODS}

\section{Plasmid constructs}

The Agrobacterium-mediated gene delivery system to express the three BMV genomic RNAs for replication and all four of the BMV-encoded proteins was developed by Gopinath et al. (2005). Construction of 1GFP1, 2GFP2, and 3GFP3 was done by flanking the green fluorescent protein (GFP) coding sequence with the $5^{\prime}$ UTR and 3' UTR of three genomic RNAs. Chimeric constructs with different combinations of the 5' and 3' UTRs of BMV RNAs flanking the GFP and deletions in RNA elements in 2GFP2 were previously described by Yi et al. (2007). Site directed mutations in the $\mathrm{CP}$ were made using primers whose sequences will be made available upon request.

\section{Agroinfiltration}

All the plasmids were introduced into Agrobacterium tumefaciens $\mathrm{C} 58 \mathrm{C} 1$ by electroporation. The cultures were grown and infiltrated into N. benthamiana as described by Gopinath et al. (2005). The cultures expressing BMV RNA1, RNA2, and RNA3 are routinely infiltrated at a concentration of $0.1 \mathrm{OD}_{595}$. Agrobacterium cultures harboring reporter constructs and $\mathrm{CP}$ varied in each experiment, and the amounts infiltrated will be specified in the figures or the figure legends. The leaves were infiltrated by gently pressing the end of a 3-mL syringe loaded with the appropriate culture to the leaf and exerting gentle pressure to flood the leaf interstitial areas. For each construct tested, at least two independently infiltrated samples were analyzed.

\section{RNA extraction and Northern blot}

Leaf tissues were macerated with disposable pestles made to fit into a microcentrifuge tube in the presence of a lysis buffer $(0.1 \mathrm{M}$ glycine at $\mathrm{pH} 9.0 ; 40 \mathrm{mM}$ EDTA, $100 \mathrm{mM} \mathrm{NaCl}, 2 \%$ SDS, and $0.05 \%$ Bentonite). The RNAs in the lysate were extracted with an equal volume of phenol and chloroform and precipitated with an equal volume of isopropanol, $7.5 \mu \mathrm{g}$ of glyoxylated RNA was loaded into a $1.2 \%$ agarose gel, and Northern blots were performed with strand-specific riboprobes, as described by Gopinath et al. (2005).

\section{RT-PCR}

Total RNA was extracted using the Mini RNA Easy kit and following the manufacturer's protocol (Qiagen) and then treated 
with RNase-free DNase I for $20 \mathrm{~min}$ at $37^{\circ} \mathrm{C}$. After inactivating DNase I, $1 \mu \mathrm{g}$ of total RNA was used for the reverse transcription with the reverse primer and SuperScript II Reverse Transcriptase, as described by the manufacturer (Invitrogen). PCR was performed with both the reverse and forward primer for 32 cycles. The PCR products were separated in the $2 \%$ agarose gel and stained with ethidium bromide.

\section{Protein analysis and Western blot}

Protein was extracted by macerating the leaf tissue with a pestle in TB buffer ( $50 \mathrm{mM}$ Tris-acetate at $\mathrm{pH} 7.4,10 \mathrm{mM} \mathrm{MgCl}_{2}, 5 \mathrm{mM}$ DTT, $1 \mathrm{mM}$ PMSF, and 10\% glycerol). The lysate was kept on ice for $20 \mathrm{~min}$ and centrifuged at $15,000 \mathrm{~g}$ for $30 \mathrm{~min}$ at $4^{\circ} \mathrm{C}$ to remove the plant cell debris and insoluble materials. The supernatant was subjected to SDS-PAGE analysis. After gel electrophoresis, the proteins were transferred to PVDF membrane for Western blot analysis with monoclonal anti-GFP antibody or rabbit anti-CP antibody.

\section{RNA synthesis and labeling for functional studies}

All of the RNA oligonucleotides for the binding assay and functional studies were synthesized by IDT (Coralville, IA). Radioactive labeling of RNA used $\left[\gamma^{-32} \mathrm{P}\right]$ ATP along with the T4 polynucleotide kinase. After phenol/chloroform extraction, RNA was precipitated with 2 volumes of ethanol and 1/10 volume of $3 \mathrm{M} \mathrm{NaAc}$ ( $\mathrm{pH}$ 5.2). The labeled RNA was dissolved in RNase-free water, heated to $95^{\circ} \mathrm{C}$, and incubated at that temperature for $2 \mathrm{~min}$, and cooled on ice for use.

\section{Purification of BMV CP}

BMV virions were purified from $N$. benthamiana leaves infiltrated with Agrobacterium expressing three genomic RNAs. At 10 dpi, the leaves were homogenized in a 1:3 ratio of extraction buffer (250 $\mathrm{mM}$ sodium acetate and $10 \mathrm{mM} \mathrm{MgCl}_{2}$ at $\mathrm{pH} 4.5$ ) and vortexed with $10 \%$ chloroform for $10 \mathrm{~min}$. After centrifugation at $15,000 \mathrm{rpm}$ for $10 \mathrm{~min}$, the supernatant was layered on a $10 \%$ sucrose cushion prepared in suspension buffer $(50 \mathrm{mM}$ sodium acetate and $10 \mathrm{mM} \mathrm{MgCl}_{2}$ at $\mathrm{pH} 4.5$ ) and subjected to ultracentrifugation for $3 \mathrm{~h}$ at $28,000 \mathrm{~g}$. The viral pellets were dissolved in suspension buffer. The pellets were subjected to banding in a $\mathrm{CsCl}_{2}$ density gradient according to the protocol of Dragnea et al. (2003). Highly purified virions were dissociated into CP by dialyzing in the buffer containing $500 \mathrm{mM} \mathrm{CaCl}_{2}, 1 \mathrm{mM}$ DTT, and $50 \mathrm{mM}$ Tris- $\mathrm{HCl}(\mathrm{pH} 7.5)$ for $24 \mathrm{~h}$ at $4^{\circ} \mathrm{C}$. Following centrifugation at $12,000 \mathrm{~g}$ for $1 \mathrm{~h}$, the supernatant was dialyzed in the buffer containing $300 \mathrm{mM} \mathrm{NaCl}, 50 \mathrm{mM}$ Tris- $\mathrm{HCl}$ ( $\mathrm{pH} 7.5$ ), and $1 \mathrm{mM}$ DTT for $24 \mathrm{~h}$. The concentration of dissociated CP was determined by spectrometry.

\section{UV cross-linking assay and gel shift experiment}

About 100 ng of purified CP was incubated with ${ }^{32} \mathrm{P}$-labeled RNA in a buffer containing $50 \mathrm{mM}$ Tris- $\mathrm{HCl}(\mathrm{pH} 7.5), 4 \mathrm{mM} \mathrm{MgCl}_{2}$, and $50 \mathrm{mM} \mathrm{NaCl}$. The reaction was irradiated with UV at $1200 \mathrm{~mJ}$ for $3 \mathrm{~min}$ and then subjected to SDS-PAGE. Radiolabeled bands were detected and quantified with a PhosphorImager. For the gel mobility shift experiments, radioactively labeled RNA was incubated with $500 \mathrm{ng}$ of dissociated CP at RT for $30 \mathrm{~min}$ in a buffer containing $50 \mathrm{mM}$ Tris- $\mathrm{HCl}$ ( $\mathrm{pH}$ 7.5), $50 \mathrm{mM} \mathrm{NaCl}, 1 \mathrm{mM}$ DTT, $1 \mathrm{mM}$ EDTA, $4 \mathrm{mM} \mathrm{MgCl}$, and $5 \%$ glycerol. The samples were electrophoresed in 3\%-12\% nondenaturing gels, and the gels were subjected to Phosphorimage analysis.

\section{Fluorescence spectroscopy}

All fluorescence measurements were made using a Perkin-Elmer luminescence spectrometer LS55 and cuvettes (Perkin-Elmer) with an optical path length of $0.4 \mathrm{~cm}$ at $22^{\circ} \mathrm{C}-23^{\circ} \mathrm{C}$. The fluoresceine-labeled RNA was at $0.2 \mu \mathrm{M}$ in a buffer containing $50 \mathrm{mM}$ Tris- $\mathrm{Cl}$ (pH 7.5) and $50 \mathrm{mM} \mathrm{NaCl}$. BMV CP was added so that the final volume of $\mathrm{CP}$ did not exceed $5 \%$ of the initial sample volume. The samples were excited with light at a wavelength of $495 \mathrm{~nm}$, and each emission was scanned with light at wavelengths from 510 to $560 \mathrm{~nm}$. The emission scan was repeated 10 times, and all results were averaged. All data were corrected for the background intensity of the buffer and for dilution. Binding data were analyzed by nonlinear least-square fitting using KaleidaGraph software (Synergy Software).

\section{RNA sample preparation for conformational studies}

Two 19-nt-long RNA sequences containing the WT B box motif or the $\mathrm{mB}$ Box RNA were transcribed from their respective DNA templates in vitro by using T7 RNA polymerase (Milligian and Uhlenbeck 1989). Gel purified RNAs were dialyzed in a buffer containing $100 \mathrm{mM} \mathrm{NaCl} 10 \mathrm{mM} \mathrm{NaPO}_{4}, 0.1 \mathrm{mM}$ EDTA (pH 6.5) and then subjected to electrophoresis in a non-denaturing $15 \%$ gel as described by Kim and Kao (2001). RNA concentrations were within the range of $2-5 \mu \mathrm{M}$. Procedures for UV melting curve analysis and nondenaturing gel electrophoresis were the same as previously described (Puglisi and Tinoco 1989; Kim et al. 2000).

\section{NMR spectroscopy}

One-dimensional (1D) Watergate, two-dimensional (2D) Watergate NOESY, and 11waterNOESY experiments were all performed at $5^{\circ} \mathrm{C}, 10^{\circ} \mathrm{C}$, and $20^{\circ} \mathrm{C}$ at various mixing times $(100-400 \mathrm{msec})$ at two different $\mathrm{pHs}$ (sodium phosphate buffer at $\mathrm{pH} 6.5$ and 5.7, $100 \mathrm{mM} \mathrm{NaCl}$ ) using a Varian VNMRS 500-MHz spectrometer and a Bruker Avance $800-\mathrm{MHz}$ NMR spectrometer. NMR spectra were processed and analyzed using NMRPipe (Delaglio et al. 1995) and NMRView (Johnson and Blevins 1994) software. 1D and $2 \mathrm{D}$ NOESY spectra in $90 \% \mathrm{H}_{2} \mathrm{O} / 10 \% \mathrm{D}_{2} \mathrm{O}$ were recorded at $5^{\circ} \mathrm{C}, 10^{\circ} \mathrm{C}$, and $20^{\circ} \mathrm{C}$, and water suppression was achieved by a watergate pulse sequence (Piotto et al. 1992) and jump-retune pulse sequence (Plateau and Gueron 1982) and Z-gradient pulse (Kay 1995) during the mixing time.

\section{Native gel electrophoresis}

WT B Box and mB Box RNA motifs were run on $15 \%$ polyacrylamide native gels (no urea) for $24-48 \mathrm{~h}$ at $4^{\circ} \mathrm{C}$ at $50-100 \mathrm{~V}$. RNA bands were stained in Toluidine Blue and destained in water.

\section{Thermal melt analysis}

The UV absorbance of the WT B Box and mB Box RNA motifs at 260 $\mathrm{nm}$ was continuously measured using the kinetics mode of a 
Genesys 2 UV/Vis Spectrometer (Thermoelectron) while increasing temperature from $8^{\circ} \mathrm{C}$ to $95^{\circ} \mathrm{C}$ using a NESLAB RTE 7 temperatureregulated bath (Thermoelectron) and a water-jacketed multiple sample holder. The melting data were processed and further analyzed using Kaleidagraph, version 3.6 (Synergy Software).

\section{SUPPLEMENTAL MATERIAL}

Supplemental material can be found at http://www.rnajournal.org.

\section{ACKNOWLEDGMENTS}

We thank our colleagues for their helpful discussions during this work. We thank D. Wemmer and J. G. Pelton at UC Berkeley for their support in the use of the Bruker $800-\mathrm{MHz}$ NMR spectrometer. We thank Mr. W. Chu for his help in using a Varian 500$\mathrm{MHz}$ NMR spectrometer at CSU East Bay. Funding is provided by the National Science Foundation grant Genome Systems MCB0641362 and an NIH GM081929 for Bioimaging and the National Science Foundation grant MCB0417248 (to C.-H.K.).

Received September 17, 2008; accepted January 16, 2009.

\section{REFERENCES}

Ahlquist, P. 2006. Parallels among positive-strand RNA viruses, reverse-transcribing viruses, and double-stranded RNA viruses. Nat. Rev. Microbiol. 4: 371-382.

Ahola, T. and Ahlquist, P. 1999. Putative RNA capping activities encoded by brome mosaic virus: Methylation and covalent binding by replicase protein 1a. J. Virol. 73: 10061-10069.

Annamalai, P. and Rao, A.L. 2005. Replication-independent expression of genome components and capsid protein of brome mosaic virus in planta: A functional role for viral replicase in RNA packaging. Virology 338: 96-111.

Bendahmane, M., Szecsi, J., Chen, I., Berg, R.H., and Beachy, R.N. 2002. Characterization of mutant tobacco mosaic virus coat protein that interferes with virus cell-to-cell movement. Proc. Natl. Acad. Sci. 99: 3645-3650.

Bhardwaj, K., Palaninathan, S., Alcantara, J.M., Yi, L.L., Guarino, L., Sacchettini, J.C., and Kao, C.C. 2008. Structural and functional analyses of the severe acute respiratory syndrome coronavirus endoribouclease. J. Biol. Chem. 283: 3655-3664.

Bol, J.F. 2005. Replication of alfamo- and ilarviruses: Role of the coat protein. Annu. Rev. Phytopathol. 43: 39-62.

Buck, K.W. 1996. Comparison of the replication of positive-stranded RNA viruses of plants and animals. Adv. Virus Res. 47: 159-251.

Bujarski, J.J., Hardy, S.F., Miller, W.A., and Hall, T.C. 1982. Use of dodecyl- $\beta$-d-maltoside in the purification and stabilization of RNA polymerase from brome mosaic virus-infected barley. Virology 119: 465-473.

Calhoun, S.L. and Rao, A.L. 2008. Functional analysis of brome mosaic virus coat protein RNA-interacting domains. Arch. Virol. 153: 231-245.

Callaway, A., Giesman-Cookmeyer, D., Gillock, E.T., Sit, T.L., and Lommel, S.A. 2001. The multifunctional capsid proteins of plant RNA viruses. Annu. Rev. Phytopathol. 39: 419-460.

Chen, J. and Ahlquist, P. 2000. Brome mosaic virus polymerase-like protein $2 \mathrm{a}$ is directed to the endoplasmic reticulum by helicaselike viral protein 1a. J. Virol. 74: 4310-4318.

Chen, J., Noueiry, A.O., and Ahlquist, P. 2001. Brome mosaic virus Protein 1a recruits viral RNA2 to RNA replication through a $5^{\prime}$ proximal RNA2 signal. J. Virol. 75: 3207-3219.
Delaglio, F., Grzesiek, S., Vuister, G.W., Zhu, G., Pfeifer, J., and Bax, A. 1995. NMRPipe: A multidimensional spectral processing system based on Unix pipes. J. Biol. NMR 6: 277-293.

Dragnea, B., Chen, C., Kwak, E.S., Stein, B., and Kao, C.C. 2003. Gold nanoparticles as spectroscopic enhancers for in vitro studies on single viruses. J. Am. Chem. Soc. 125: 6374-6375.

French, R. and Ahlquist, P. 1987. Intercistronic as well as terminal sequences are required for efficient amplification of brome mosaic virus RNA3. J. Virol. 61: 1457-1465.

Gelvin, S.B. 2003. Agrobacterium-mediated plant transformation: The biology behind the "gene-jockeying" tool. Microbiol. Mol. Biol. Rev. 67: 16-37.

Gopinath, K., Dragnea, B., and Kao, C.C. 2005. Interaction between brome mosaic virus proteins and RNAs: Effects on RNA replication, protein expression, and RNA stability. J. Virol. 79: 1422214234.

Grdzelishvili, V.Z., Garcia-Ruiz, H., Watanabe, T., and Ahlquist, P. 2005. Mutual interference between genomic RNA replication and subgenomic mRNA transcription in brome mosaic virus. J. Virol. 79: $1438-1451$.

Guogas, L.M., Laforest, S.M., and Gehrke, L. 2005. Coat protein activation of alfalfa mosaic virus replication is concentration dependent. J. Virol. 79: 5752-5761.

Ilkow, C.S., Mancinelli, V., Beatch, M.D., and Hobman, T.C. 2008. Rubella virus capsid protein interacts with poly(A)-binding protein and inhibits translation. J. Virol. 82: 4284-4294.

Iyer, L.M. and Hall, T.C. 2000. Virus recovery is induced in brome mosaic virus $\mathrm{p} 2$ transgenic plants showing synchronous complementation and RNA2 specific silencing. Mol. Plant Microbe Interact. 13: 247-258.

Janda, M. and Ahlquist, P. 1993. RNA-dependent replication, transcription, and persistence of brome mosaic virus RNA replicons in S. cerevisiae. Cell 72: 961-970.

Johnson, B.A. and Blevins, R.A. 1994. NMR View: A computer program for the visualization and analysis of NMR data. J. Biol. NMR 4: 603-614.

Kao, C.C. and Ahlquist, P. 1992. Identification of domains required for direct interaction of the helicase-like and polymerase-like RNA replication proteins of brome mosaic virus. J. Virol. 66: 72937302.

Kay, L.E. 1995. Field gradient techniques in NMR spectroscopy. Curr. Opin. Struct. Biol. 5: 674-681.

Kim, C.H. and Kao, C. 2001. A mutant viral RNA promoter with an altered conformation retains efficient recognition by a viral RNA replicase through a solution-exposed adenine. RNA 7: 1476-1485.

Kim, C.H., Kao, C., and Tinoco, I. 2000. RNA motifs that determine specificity between a viral replicase and its promoter. Nat. Struct. Biol. 7: 415-423.

Kong, F., Sivakumaran, K., and Kao, C.C. 1999. The N-terminal half of the brome mosaic virus la protein has RNA capping-associated activities: Specificity for GTP and S-adenosylmethionine. Virology 259: 200-210.

Miller, W.A. and White, A.K. 2006. Long-distance RNA-RNA interactions in plant virus gene expression and replication. Annu. Rev. Phytopathol. 44: 447-467.

Miller, W.A., Dreher, T.W., and Hall, T.C. 1985. Synthesis of brome mosaic virus subgenomic RNA in vitro by internal initiation on (-)-sense genomic RNA. Nature 313: 68-70.

Milligan, J.F. and Uhlenbeck, O.C. 1989. Synthesis of small RNAs using T7 RNA polymerase. Methods Enzymol. 180: 51-62.

Neeleman, L., Olsthoorn, R.C., Linthorst, H.J., and Bol, J.F. 2001. Translation of a nonpolyadenylated viral RNA is enhanced by binding of viral coat protein or polyadenylation of the RNA. Proc. Natl. Acad. Sci. 98: 14286-14291.

Noueiry, A.O. and Ahlquist, P. 2003. Brome mosaic virus RNA replication: Revealing the role of the host in RNA virus replication. Annu. Rev. Phytopathol. 41: 77-98.

Noueiry, A.O., Chen, P., and Ahlquist, P. 2000. A mutant allele of essential, general translation initiation factor DED1 selectively 
inhibits translation of a viral mRNA. Proc. Natl. Acad. Sci. 97: 12985-12990.

Petersheim, M. and Turner, D.H. 1983. Base-stacking and basepairing contributions to helix stability: Thermodynamics of double-helix formation with CCGG, CCGGp, CCGGAp, ACCGGp, CCGGUp, and ACCGGUp. Biochemistry. 22: 256-263.

Piotto, M., Saudek, V., and Sklenar, V. 1992. Gradient-tailored excitation for single-quantum NMR spectroscopy of aqueous solutions. J. Biol. NMR 2: 661-665.

Plateau, P. and Gueron, M. 1982. Exchangeable proton NMR without baseline distortion using strong-pulse sequences. J. Am. Chem. Soc. 104: $7310-7311$.

Puglisi, J.D. and Tinoco, I. 1989. Absorbance melting curves of RNA. Methods Enzymol. 180: 304-325.

Qu, F., Ren, T., and Morris, T.J. 2003. The coat protein of turnip crinkle virus suppresses post-transcriptional gene silencing at an early initiation step. J. Virol. 77: 511-522.

Rao, A.L. 2006. Genome packaging by spherical plant RNA viruses. Annu. Rev. Phytopathol. 44: 61-87.

Reichert, V.L., Choi, M., Petrillo, J.E., and Gehrke, L. 2007. Alfalfa mosaic virus coat protein bridges RNA and RNA-dependent RNA polymerase in vitro. Virology 364: 214-226.

Schwartz, M., Chen, J., Janda, M., Sullivan, M., den Boon, J., and Ahlquist, P. 2002. A positive-strand RNA virus replication complex parallels form and function of retrovirus capsids. Mol. Cell 9: 505-514.

Schwartz, M., Chen, J., Lee, W.M., Janda, M., and Ahlquist, P. 2004. Alternate, virus-induced membrane rearrangements support positivestrand RNA virus genome replication. Proc. Natl. Acad. Sci. 101: 11263-11268.

Shimoike, T., Mimori, S., Tani, H., Matsuura, Y., and Miyamura, T. 1999. Interaction of hepatitis $C$ virus core protein with viral sense RNA and suppression of its translation. J. Virol. 73: 9718-9725.

Takeuchi, O. and Akira, S. 2007. Recognition of viruses by innate immunity. Immunol. Rev. 220: 214-224.

Turner, D.H., Sugimoto, N., and Freier, S.M. 1988. RNA structure prediction. Annu. Rev. Biophys. Chem. 17: 167-192.
Voinnet, O. 2005. Induction and suppression of RNA silencing: Insights from viral infections. Nat. Rev. Genet. 6: 206-220.

Wang, X., Lee, W.M., Watanabe, T., Schwartz, M., Janda, M., and Ahlquist, P. 2005. Brome mosaic virus la nucleoside triphosphatase/helicase domain plays crucial roles in recruiting RNA replication templates. J. Virol. 79: 13747-13758.

Wierzchoslawski, R., Urbanowicz, A., Dzianott, A., Figlerowicz, M., and Bujarski, J.J. 2006. Characterization of a novel 5' subgenomic RNA3a derived from RNA3 of Brome mosaic bromovirus. J. Virol. 80: $12357-12366$.

Witherell, G.W., Gott, J.M., and Uhlenbeck, O.C. 1991. Specific interaction between RNA phage coat proteins and RNA. Prog. Nucleic Acid Res. Mol. Biol. 40: 185-220.

Wolf, M., Dimitrova, M., Baumert, T.F., and Schuster, C. 2008. The major form of hepatitis $C$ virus alternate reading frame protein is suppressed by core protein expression. Nucleic Acids Res. 36: 30543064.

Yi, G. and Kao, C.C. 2008. Cis- and trans-acting functions of brome mosaic virus protein 1a in genomic RNA1 replication. J. Virol. 82: 3045-3053.

Yi, G., Gopinath, K., and Kao, C.C. 2007. Selective repression of translation by the brome mosaic virus la replication protein. $J$. Virol. 81: 1601-1609.

Zhang, X., Kim, C.H., and Kao, C. 2003. RNA secondary structure inhibits the initiation of RNA synthesis by a viral RNA replicase. RNA 9: 555-565.

Zhu, J., Gopinath, K., Murali, A., Yi, G., Hayward, S.D., Zhu, H., and Kao, C. 2007. RNA-binding proteins that inhibit RNA virus infection. Proc. Natl. Acad. Sci. 104: 3129-3134.

Zuker, M. 2003. Mfold web server for nucleic acid folding and hybridization prediction. Nucleic Acids Res. 31: 3406-3415.

Zuker, M., Mathews, D.H., and Turner, D.H. 1999. Algorithms and thermodynamics for RNA secondary structure prediction: A practical guide. In RNA Biochemistry and Biotechnology (eds. J. Barciszewski and B.F.C. Clark), pp. 11-43. Kluwer Academic, Dordrecht, The Netherlands. 

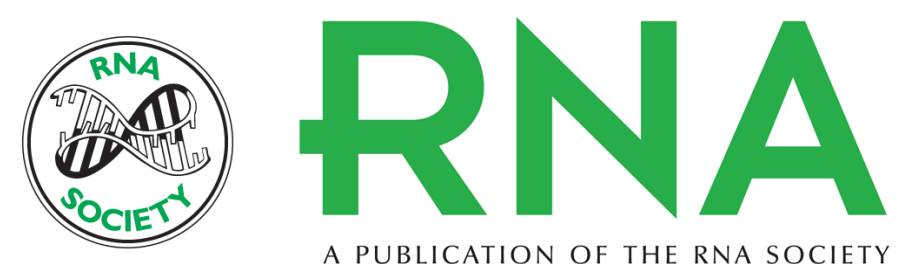

A PUBLICATION OF THE RNA SOCIETY

\section{Brome mosaic virus capsid protein regulates accumulation of viral replication proteins by binding to the replicase assembly RNA element}

Guanghui Yi, Ester Letteney, Chul-Hyun Kim, et al.

RNA 2009 15: 615-626 originally published online February 23, 2009

Access the most recent version at doi:10.1261/rna.1375509

Supplemental
Material http://rnajournal.cshlp.org/content/suppl/2009/02/23/rna.1375509.DC1

References This article cites 56 articles, 23 of which can be accessed free at:

http://rnajournal.cshlp.org/content/15/4/615.full.html\#ref-list-1

License

Email Alerting Receive free email alerts when new articles cite this article - sign up in the box at the Service top right corner of the article or click here.

To subscribe to $R N A$ go to:

http://rnajournal.cshlp.org/subscriptions 